\title{
Anurans as Intermediate and Paratenic Hosts of Helminth Infections in the Rainforest and Derived Savanna Biotopes of Southern Nigeria
}

\begin{abstract}
Abigail A. Imasuen, Habibat J. Ozemoka, and Martins S. O. Aisien
Laboratory of Parasitology Research, Department of Animal and Environmental Biology, Faculty of Life Sciences, University of Benin, P.M.B. 1154, Benin City, Edo State 300001, Nigeria

Correspondence should be addressed to Martins S. O. Aisien, aisien@uniben.edu

Received 26 March 2012; Revised 17 June 2012; Accepted 18 July 2012

Academic Editor: Tobias Wang

Copyright ( $) 2012$ Abigail A. Imasuen et al. This is an open access article distributed under the Creative Commons Attribution License, which permits unrestricted use, distribution, and reproduction in any medium, provided the original work is properly cited.

Anurans from the rainforest (Okomu National Park) and derived savanna (Agbede) locations in Nigeria were investigated for their role either as intermediate or paratenic hosts of helminth infections. A total of 269 anuran specimens (157 from the Okomu National Park and 112 from Agbede) were examined. Metacercariae of a strigeoid trematode, two nematode species, a proteocephalid cestode, and an acanthocephalan were recovered from infected hosts. Except for the strigeoid trematode, which was only recorded in the rainforest, there was no ecological dichotomy in the distribution of the larval parasites recorded. Tree frogs from the rainforest only served as second intermediate hosts for the strigeoid trematode. The two nematode larvae (type I and type II) found in the body cavity of the infected host are believed to use them as paratenic hosts. Tree frogs were the predominant intermediate hosts of the proteocephalid cestode larvae in the rainforest, while Ptychadena and Phrynobatrachus spp. served this function in the derived savanna. The occurrence of cystacanths in the anurans from both biotopes confirms their known role as paratenic host for acanthocephalans. Afrixalus dorsalis is a new host record for the ascaridoid nematode while the finding of the strigeoid trematode, the proteocephalid cestode larvae and acanthocephalan cystacanths in the anurans investigated represents new geographical records.
\end{abstract}

\section{Introduction}

Anurans are definitive hosts to several classes of helminth parasites, including Cestoda, Monogenea, Trematoda, Nematoda, and Acanthocephala. Apart from this established role, anurans also serve as intermediate hosts [1-6] or as paratenic hosts $[3,7-12]$, in the trophical transmission of helminth infections to a number of vertebrate hosts. Reports of these alternative roles have received the attention of various investigators in Europe $[2,5,10,13,14]$, Canada [6], USA [1, 8], and South America $[4,11,12]$. Except for the report of Jackson and Tinsley [9], discussing the use of hymenochirine anurans as transport hosts in camallanid nematode life cycles and the anecdotal reference of Aisien et al. $[15,16]$ to the same role in the amphibians of the savanna in Nigeria, there is a dearth of information on these phenomena in Africa.
In a recent study of the helminth parasites of anurans in two biotopes (a protected rainforest location and a derived savanna habitat) in southwestern Nigeria, we found a good number of encysted helminth parasites which we suspect use anurans either as intermediate or transport hosts. In this paper we discuss the roles of the infected anurans in the trophic transmission of these parasites to various vertebrate hosts in the two biotopes.

\section{Materials and Methods}

Amphibians used for this study were collected from the rainforest (Okomu National Park, $6^{\circ} 15^{\prime} \mathrm{N}$ and $6^{\circ} 25^{\prime} \mathrm{N} ; 5^{\circ} 9^{\prime} \mathrm{E}$ and $5^{\circ} 23^{\prime} \mathrm{E}$ ) and the savanna-mosaic (Agbede, $6^{\circ} 86^{\prime} \mathrm{N}$, $6^{\circ} 25^{\prime} \mathrm{E}$ ), in Edo State of Nigeria, between April, 2007 and October, 2008. Prior to examination, the amphibians were 
killed by immersion in Benzocaine solution. The amphibians were dissected and the gastrointestinal tract (oesophagus/stomach, small intestine, large intestine/rectum), lungs, liver/gall bladder, urinary bladder, and the body cavity were examined for encysted larval stages of helminth parasites.

Cysts of helminth parasites observed in the various parts of the body were isolated, crushed under cover slip pressure to identify the encysted parasite group, after which microphotographs were taken. Metacercariae recovered from tree frogs were incubated at $37^{\circ} \mathrm{C}$ in normal saline $(0.85 \%)$ containing $0.5 \%$ pepsin to free the juvenile parasite. Larvae of cestodes, trematodes and acanthocephalans were isolated and fixed in 5\% formol saline. The parasites were washed free of the fixative in several changes of tap water and then stained overnight in a dilute solution of acetocarmine. The specimens were thereafter dehydrated and mounted in Canada balsam.

\section{Results}

A total of 269 amphibian specimens were examined in this study, 157 from the Okomu National Park and 112 from Agbede. Larvae of helminth parasites encountered included those of a trematode, a proteocephalid cestode, two nematode species, and an acanthocephalan.

Metacercariae of the trematode recovered were found lying free in the body cavity of tree frogs including Leptopelis hyloides, Afrixalus dorsalis, A. cog. nigeriensis, Hyperolius sylvaticus, Hyperolius sp. 1, and Chiromantis rufescens, only at the Okomu National Park. The prevalence and mean intensity of infection are presented in Table 1. Although $L$. hyloides, A. dorsalis and Hyperolius sp. had higher prevalence values, intensity of infection was higher in C. rufescens and $H$. sylvaticus. The metacercariae cysts consisted of rounded bodies divided into an outer hyaline layer with projections at the outer fringes and a dark ovoid inner core which enclosed the developing larvae (Figure 1(a)). The cysts ranged from $399 \mu \mathrm{m}-1,236.9 \mu \mathrm{m}$ (mean: $532.33 \mu \mathrm{m}$ ) in length and 212.8$947.6 \mu \mathrm{m}$ (mean: $392.7 \mu \mathrm{m}$ ) in diameter. The dimensions of the outer hyaline layer ranged from $252.7 \mu \mathrm{m}-798.0 \mu \mathrm{m}$ (mean: $333.8 \mu \mathrm{m}$ ) by $119.7 \mu \mathrm{m}-665.0 \mu \mathrm{m}$ (mean: $271 \mu \mathrm{m}$ ). The ovoid inner core measurements ranged from $146.3 \mu \mathrm{m}-$ $438.9 \mu \mathrm{m}$ (mean: $199.5 \mu \mathrm{m}$ ) by $93.1 \mu \mathrm{m}-292.6 \mu \mathrm{m}$ (mean: $122.4 \mu \mathrm{m})$.

The metacercariae excysted within 30 minutes of incubation at $37^{\circ} \mathrm{C}$ in normal saline containing $0.5 \%$ pepsin (Figure 1(b)). They were observed to be juveniles of a strigeoid trematode (Figure 1(c)) which ranged from $333 \mu \mathrm{m}$ to $433 \mu \mathrm{m}$ (mean: $376 \mu \mathrm{m}$ ) in length.

Two encysted nematode larval types were recovered from the anurans investigated. Both larval types occurred in the anurans of the rainforest as well as those of the derived savanna (Tables 2 and 3). The type I larvae (Figures 2(a) and 2(b)) were found attached to the organs of the viscera (liver, walls of the stomach and the small intestine) in Leptopelis spiritusnoctis, Hyperolius fusciventris, $H$. fusc. burtoni, $H$. guttulatus, H. picturatus, Phrynobatrachus liberiensis, P. plicatus, Silurana tropicalis, and Pty. pumilio in the forest (Table 2)
TABle 1: Prevalence of strigeoid trematode metacercariae in tree frogs at the Okomu National Park.

\begin{tabular}{lccc}
\hline Host & No examined & Prevalence (\%) & Mean intensity \\
\hline L. hyloides & 30 & 16.7 & 9.0 \\
A. dorsalis & 108 & 13.8 & 3.3 \\
A. cog. nigeriensis & 25 & 4.0 & 15.0 \\
H. sylvaticus & 25 & 4.5 & 28.0 \\
Hyperolius sp. & 17 & 11.7 & 10.0 \\
C. rufescens & 64 & 1.6 & 30.0 \\
\hline
\end{tabular}

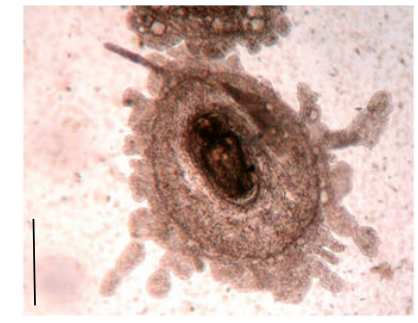

(a)

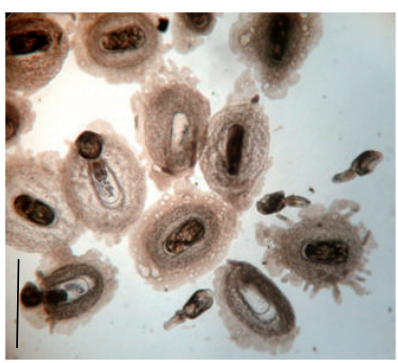

(b)

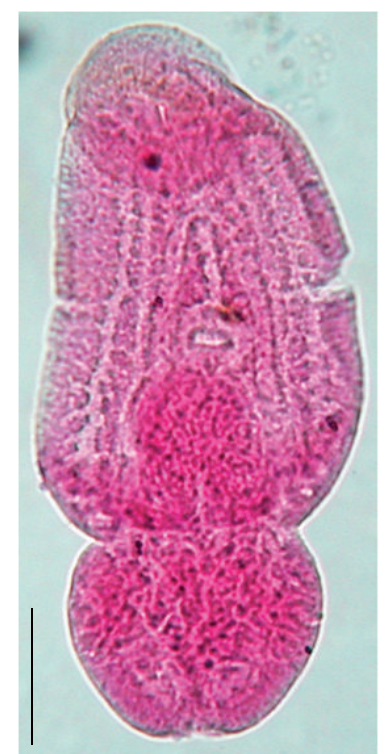

(c)
Figure 1: Strigeoid trematode recovered from the body cavity of some tree frogs at the Okomu National Park. (a), Unexcysted metacercariae; (b), metacercariae in the excystment medium; (c), stained specimen of the excysted juvenile parasite. Scale bar: $A=$ $200 \mu \mathrm{m}, B=500 \mu \mathrm{m}, C=50 \mu \mathrm{m}$.

TABle 2: Prevalence of nematode larvae type 1 in anurans at the Okomu National Park.

\begin{tabular}{lccc}
\hline Host & No examined & Prevalence (\%) & Mean intensity \\
\hline L. spirtusnoctis & 15 & 6.7 & 27 \\
H. fusciventris & 12 & 8.3 & 3.0 \\
H. fusc. burtoni & 15 & 6.7 & 2.0 \\
H. guttulatus & 02 & 50.0 & 18.0 \\
H. picturatus & 21 & 9.5 & 3.0 \\
P. liberiensis & 25 & 4.0 & 1.0 \\
P. plicatus & 33 & 3.0 & 3.0 \\
S. tropicalis & 142 & 0.7 & 9.0 \\
Pty. pumilio & 35 & 34.3 & 4.0 \\
\hline
\end{tabular}

and in Ptychadena oxyrhynchus and Pty. mascareniensis in the derived savanna (Table 3 ). In this cyst type, the single nematode larva contained therein could be seen through the semitransparent cyst membrane (Figure 2(a)). The intestinal tract 
TABLe 3: Prevalence of larval helminthes in the anurans of Agbede.

\begin{tabular}{|c|c|c|c|c|c|}
\hline Larval type & Host & No examined & Prevalence & Mean intensity & Site of encystment \\
\hline \multirow{2}{*}{ Nematoda (larva I) } & Ptychadena oxyrhynchus & 11 & 9.1 & 3.0 & 2 \\
\hline & Pty. mascareniensis & 17 & 11.8 & 3.0 & 1 \\
\hline \multirow{2}{*}{ Ascaridoid larva (type II) } & Pty.pumilio & 17 & 5.9 & 4.0 & 4 \\
\hline & Pty. mascareniensis & 17 & 5.9 & 3.0 & 4 \\
\hline \multirow{4}{*}{ Proteocephalid cestode } & Pty. bibroni & 40 & 20.0 & 10.3 & $2,3,5$ \\
\hline & Pty. pumilio & 17 & 6.9 & 1.0 & 2 \\
\hline & Pty. mascareniensis & 17 & 5.9 & 8.0 & 2 \\
\hline & Phrynobatrachus natalensis & 27 & 3.7 & 4.0 & 3 \\
\hline \multirow{2}{*}{ Acanthocephala } & Pty. pumilio & 17 & 11.8 & 1.0 & 1,2 \\
\hline & Phrynobatrachus natalensis & 27 & 14.8 & 3.0 & $1,2,6$ \\
\hline
\end{tabular}

Wall of 1: stomach; 2: small intestine; 3: large intestine; 4: body cavity; 5: urinary blabber; 6: liver.

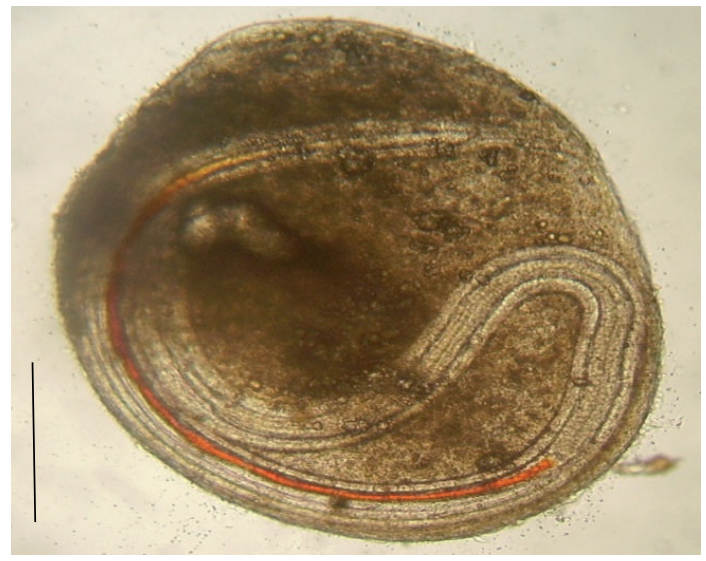

(a)

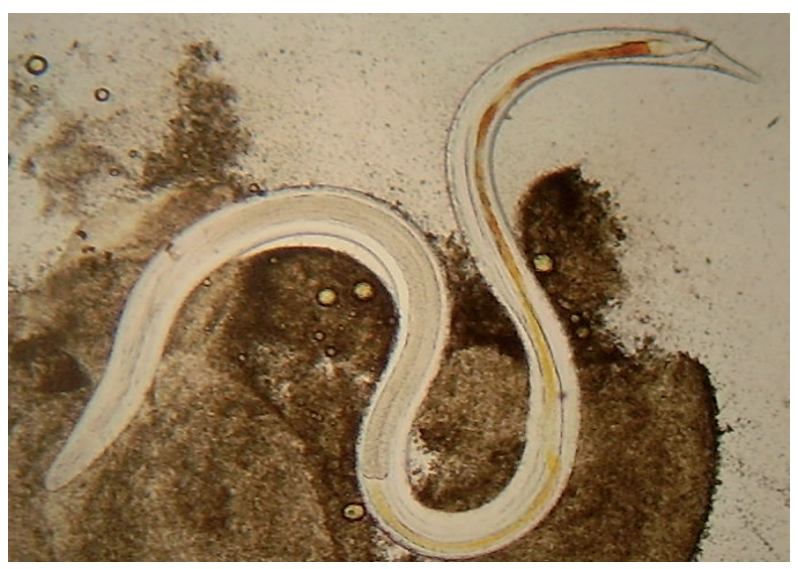

(b)

Figure 2: (a), Nematode cyst type I (intact); (b), mechanically excysted larva. Scale bar: $0.2 \mathrm{~mm}$.

was very distinct as it was stained red, possibly by a blood meal. Except for the prevalence of the parasite in H. guttulatus (50.0\%) and Pty. pumilio (34.3\%) in the rainforest and $11.8 \%$ recorded in Pty. mascareniensis (savanna), prevalence values for this nematode larva were generally low. The intensity of infection was also low in most of the anurans examined in the rainforest (Table 2 ) and the savanna (Table 3 ).

The nematode larvae type II was that of an ascaridoid nematode (Figure 3). The larvae were found encysted in thin layer of transparent cysts found in the body cavity, especially close to the liver and in few instances within the urinary bladder of the host. Anuran hosts harbouring these larvae in the forest were A. dorsalis and Pty. pumilio with prevalence values of $1.8 \%$ and $20.0 \%$, respectively. Ptychadena pumilio and Pty. mascareniensis harboured this nematode in the derived savanna and the prevalence values are as shown in Table 3.

The proteocephalid cestode larvae (Figure 4(a)) were found encysted on walls of the gastrointestinal tract of anurans from the derived savanna (Table 3 ) and the rainforest (Table 4). Contained in the cysts were cestode larvae with unsegmented body and four suckers on their scolices (Figures 4(b), 4(c)). While the parasite was recovered from

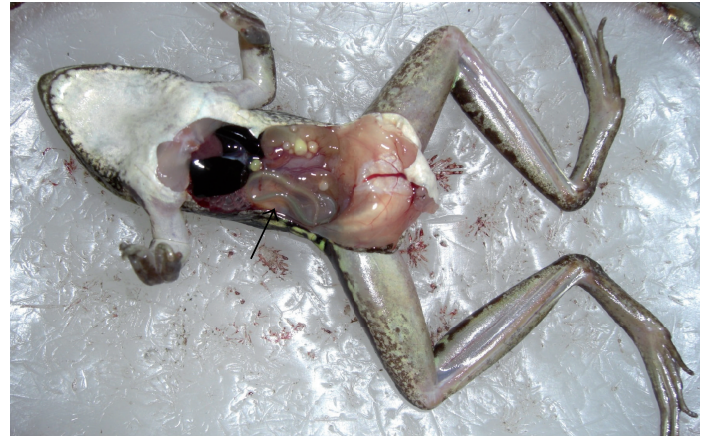

FIGURE 3: Showing the encysted ascaridoid larva in the body cavity of a Ptychadena sp.

only four hosts in the savanna (Table 3 ) with prevalence values ranging from 17 to $40 \%$, these larvae were found in the viscera of 15 anurans in the rainforest, most of which were tree frogs (Table 4). Prevalence and mean intensity values are also shown in Table 4.

Cysticanths of the acanthocephalan found (Figure 5(a)) were attached to various organs of the viscera (stomach, 


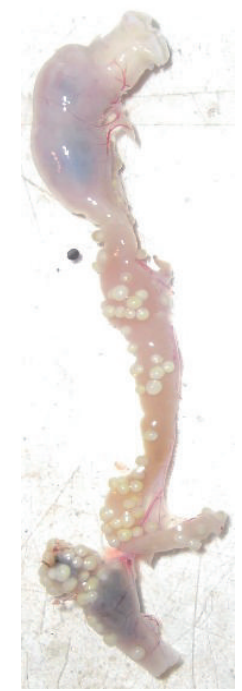

(a)

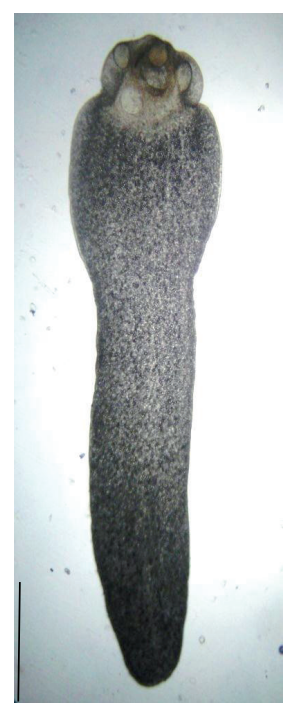

(b)

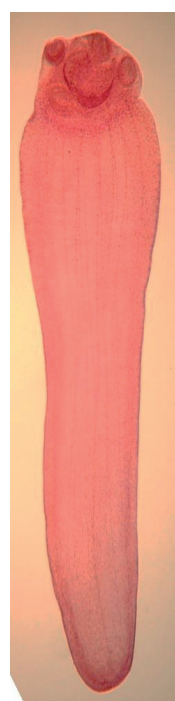

(c)
Figure 4: (a) Cysts of cestodes attached to the small intestine, large intestine/rectum of Ptychadena bibroni from Agbede; (b) and (c), mechanically excysted proteocephalid cestode larva (unstained and stained, resp.). Scale bar: $0.5 \mathrm{~mm}$.

TABLE 4: Prevalence of proteocephalid cestode larvae in the anurans at the Okomu National Park.

\begin{tabular}{lccc}
\hline Host & No examined & Prevalence (\%) & Mean intensity \\
\hline L. hyloides & 30 & 20.0 & 2.0 \\
A. dorsalis & 108 & 25.0 & 1.2 \\
A. cog. nigeriensis & 25 & 40.0 & 1.2 \\
H. fusciventris & 12 & 41.7 & 2.2 \\
H. fusc. burtoni & 15 & 13.3 & 2.2 \\
H. guttulatus & 02 & 50.0 & 6.0 \\
H. picturatus & 21 & 23.8 & 4.0 \\
H. sylvaticus & 22 & 18.1 & 6.7 \\
Hyperolius sp. 1 & 17 & 17.6 & 13.7 \\
P. liberiensis & 25 & 32.0 & 2.9 \\
P. plicatus & 33 & 42.2 & 1.7 \\
S. tropicalis & 142 & 7.7 & 4.9 \\
Pty. longirostris & 27 & 14.3 & 4.8 \\
Pty. pumilio & 35 & 28.6 & 4.5 \\
C. rufescens & 64 & 1.4 & 7.0 \\
\hline
\end{tabular}

small intestine, the liver, and the urinary bladder) of anurans from both biotopes. More hosts (15) harboured these larvae in the forest than was observed in the savanna (02). The prevalence and mean intensity values in the two biotopes are shown in Tables 3 and 5, respectively. The cysts occurred either singly or in pairs (Figure 5(a)). The dimensions of the cysts are as follows: length, $1.22 \mathrm{~mm}-1.82 \mathrm{~mm}$ (mean: $1.44 \mathrm{~mm}$ ); width, $0.69 \mathrm{~mm}-1.16 \mathrm{~mm}$ (mean: $0.81 \mathrm{~mm}$ ). The specific identity of this parasite was difficult to establish because the proboscis of the excysted parasite was not fully extruded. From the body shape, the parasite is thought to bear resemblance to Corynosoma sp. (Bursey, R.C. personal communication).

\section{Discussion}

Amphibians are preys to a wide variety of predators, including birds, snakes, turtles, and other reptiles and even predatory anurans such as Hoplobatrachus occipitalis. In this regard, amphibians could really serve to transfer parasitic infections to several trophic levels of the food web. In the rainforest the range of hosts harbouring larval helminths was wider and this is understandably so since the forest harbours a higher diversity of amphibian species. In this study, only Ptychadena and Phrynobatrachus spp. harboured larval helminth parasites in the derived savanna. Other savanna dwelling anurans previously known to harbour encysted parasites (ascaridoid larvae) include B. regularis and Dicroglossus occipitalis $[15,16]$.

Apart from their known role as definitive hosts to helminth parasites [15-18], anurans from the savanna and rainforest seem to be engaged in other roles as shown by the larval helminthes recovered from them in this study. A number of tree frogs were found harbouring metacercariae of the strigeoid trematode in the rainforest. This report is the first record of a strigeoid trematode in the amphibians of Nigeria. Although the identity of this parasite (with regards to the genus and species) is yet to be established, the involvement of an amphibian in its life cycle is consistent with what has been reported for other strigeoid trematodes, which involve either tadpoles or adult amphibians as second intermediate hosts [7]. In these amphibians, the larval stages are present either as metacercariae or mesocercariae. Until the life cycle of this trematode is elucidated, the question as to which form of the two is harboured by the anurans at the Okomu National Park can only be a matter of conjecture. But judging by the arboreal habitat of these frogs, molluscs, which are the first intermediate host of these parasites, are unlikely to be part of their diet. We therefore presume that these frogs are infected as tadpoles, and the parasites remain viable in those metamorphs that emerge from water to continue their terrestrial existence as tree frogs. It can be inferred therefore that the anurans in this instance are serving as second intermediate host, and the parasite are present as metacercariae. The parasites may form mesocercariae in paratenic hosts such as snakes, from which the definitive host (possibly birds and carnivores) can acquire the infection.

The nematode larvae type I was observed to occur in a wider range of host species, having been recorded in 9 anurans in the forest (Table 2) and two in the savanna (Table 3). The identity of this nematode is unknown, but from the intestinal content, it appears to be a haematophagous parasite. Although the structure of the oesophagus bears semblance to those of Physaloptera species it is unlikely that this parasite belongs to this group since the larvae of Physaloptera species have only been observed to occur in the stomachs of anurans in Nigeria (unpublished data) and elsewhere [19]. The location of this parasite in the infected 


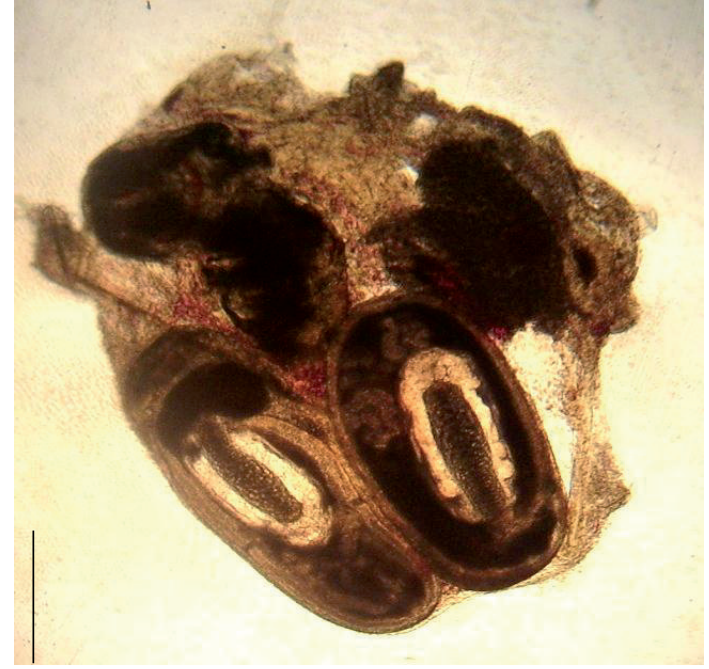

(a)

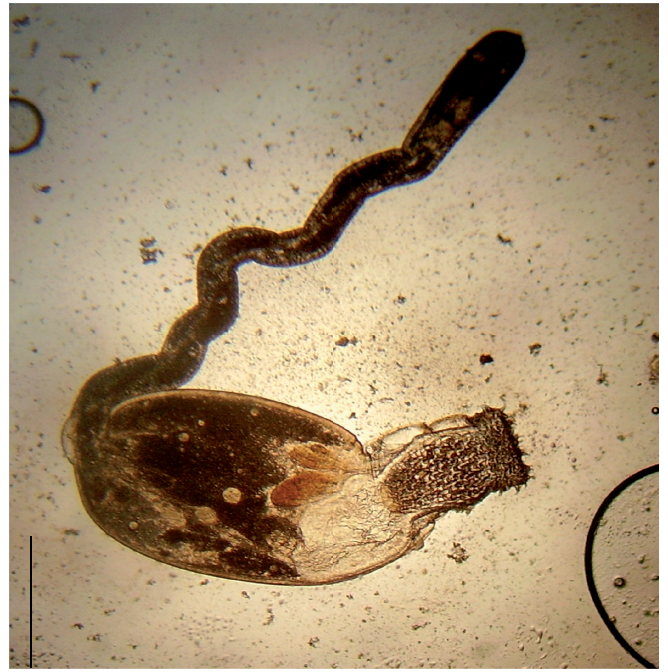

(b)

Figure 5: (a) Acanthocephala cyst (intact), (b) mechanically excysted Acanthocephala juvenile. Scale bar $=0.5 \mathrm{~mm}$.

TABle 5: Prevalence of acanthocephalan cysts in anurans at the Okomu National Park.

\begin{tabular}{lccc}
\hline Host & No examined & Prevalence (\%) & Mean intensity \\
\hline L. hyloides & 30 & 26.7 & 8.0 \\
H. fusciventris & 12 & 16.7 & 2.0 \\
H. fusc. burtoni & 15 & 20.0 & 3.0 \\
H. picturatus & 21 & 9.5 & 2.0 \\
H. sylvaticus & 22 & 22.7 & 5.0 \\
Hyperolius sp. 1 & 17 & 17.6 & 3.0 \\
Hyperolius sp. 2 & 09 & 33.3 & 3.0 \\
A.dorsalis & 108 & 12.1 & 3.6 \\
A. cog. nigeriensis & 26 & 23.1 & 6.0 \\
P. liberiensis & 25 & 3.0 & 4.0 \\
P. plicatus & 33 & 21.2 & 7.1 \\
A. albolabris & 11 & 18.2 & 2.0 \\
P. pumilio & 35 & 22.8 & 8.0 \\
S. tropicalis & 142 & 8.5 & 12.0 \\
C. rufescens & 64 & 17.1 & 11.0 \\
\hline
\end{tabular}

hosts and the stage encountered is highly suggestive of the parasite using the anurans as transport host to reach the definitive host.

The nematode larvae type II 1 is that of an ascaridoid nematode which has been reported in previous investigations undertaken in forest and savanna locations in Nigeria [15, $16,18]$. In these earlier reports, these larvae occurred in the body cavity of B. regularis, D. occipitalis, Pty. mascareniensis, Pty. pumilio, and Pty. longirostris. A new host recorded in this study is A. dorsalis, which unlike other hosts is an arboreal species. Apart from amphibians, these ascaridoids have also been recovered from the body cavity of the Agama lizard [20]. It is likely that these ascaridoid nematodes are Ophidascaris species which was investigated in some detail by Sprent [21]. Sprent [21] had experimentally demonstrated the use of frogs as intermediate host by Ophidascaris obconica. It is therefore possible that the anurans harbouring these ascaridoids in the rainforest and savanna of Nigeria play a similar role in the life cycle of these nematodes.

The larval cestodes encountered in this study were those of a proteocephalid cestode. This is the first record of these parasites in anurans studied in the different bioclimatic zones of Nigeria. It is likely that they may have been overlooked in previous studies on account of their very small size. Aisien et al. [19] found this parasite in four anurans (Hoplobatrachus occipitalis, Hyperolius nitidulus, Phrynobatrachus latifrons, and P. natalensis) at the Pendjari Biosphere Reserve in Benin Republic, which is located in the savanna region of the country. In the derived savanna of Nigeria (Agbede) a small number of hosts also harboured this parasite. In contrast, the parasite was recorded in 15 anurans in the rainforest at the Okomu National Park. Larval proteocephalids infections in amphibians have been reported elsewhere [2224]. According to Ulmer and James [22], the plerocercoids encountered in Rana pipiens are probably immature stages of Ophiotaenia perspicua, a cestode parasite of garter and water snakes. A number of Ophiotaenia spp. including O. ophiodex and $O$. nigriocollis also infect snakes in Africa [25-28]. The anurans harbouring larval proteocephalid cestodes may be intermediate hosts of the Ophiotaenids parasitizing snakes in the rainforest and the derived savanna of Nigeria.

Adult acanthocephalans parasitize the intestine of their respective anuran hosts [29-31]. The presence of cysticanths in the organs of the viscera of anurans, as found in this study, is usually indicative of a role as paratenic hosts $[4,7,12]$. According to Santos and Amato [12], paratenic hosts act as a trophic bridge between the intermediate and definitive host, concentrating and passing the cystacanths to the definitive host. The identity of the acanthocephalan infecting these anurans needs further clarification. The genus Corynosoma to which it is tentatively assigned are parasites of piscivorous birds [7]. It is possible that these birds also feed on 
amphibians and thereby acquire the infection. Whereas only two anurans carried these cystacanths in the savanna (Agbede), 15 anurans, mainly tree frogs served as paratenic hosts in the forest (Okomu). In the Pendjari Biosphere Reserve (savanna) in Benin Republic, five anurans including Bufo pentoni, Phrynobatrachus latifrons, $P$. natalensis, Pty. pumilio, and Pty. telini served as transport host for acanthocephalan cystacanths [19]. It thus appears that in the drier habitats, terrestrial and semi aquatic hosts are utilized, while in the rainforest tree frogs predominantly serve this purpose.

\section{Acknowledgments}

The authors are grateful to Mr. Elisha Enabulele and Mr. Festus Arijode for their technical assistance during this investigation.

\section{References}

[1] S. K. Sessions and S. B. Ruth, "Explanation for naturally occurring supernumerary limbs in amphibians," The Journal of Experimental Zoology, vol. 254, no. 1, pp. 38-47, 1990.

[2] G. Bolt, J. Monrad, F. Frandsen, P. Henriksen, and H. H. Dietz, "The common frog (Rana temporaria) as a potential paratenic and intermediate host for Angiostrongylus vasorum," Parasitology Research, vol. 79, no. 5, pp. 428-430, 1993.

[3] F. Moravec and H. Kaiser, "Brevimulticaecum sp. larvae (Nematoda: Anisakidae) from the frog Hyla minuta peters in Trinidad," Journal of Parasitology, vol. 80, no. 1, pp. 154-156, 1994.

[4] P. Torres and S. Puga, "Occurrence of cystacanths of Centrorhynchus sp. (Acanthocephala:Centrorhynchidae) in toads of the genus Eupsophus in Chile," Memórias do Instituto Oswaldo Cruz, vol. 91, no. 6, pp. 717-719, 1996.

[5] O. Krone and W. J. Streich, "Strigea falconispalumbi in Eurasian buzzards from Germany," Journal of Wildlife Diseases, vol. 36, no. 3, pp. 559-561, 2000.

[6] G. W. Thiemann and R. J. Wassersug, "Biased distribution of trematode metacercariae in the nephric system of Rana tadpoles," Journal of Zoology, vol. 252, no. 4, pp. 534-538, 2000.

[7] B. B. Nickol, "Epizootiology," in Biology of the Acanthocephala, D. W. T. Crompton and B. B. Nickol, Eds., pp. 307-346, Cambridge University Press, Cambridge, UK, 1985.

[8] M. L. Eberhard and F. H. Brandt, "The role of tadpoles and frogs as paratenic hosts in the life cycle of Dracunculus insignis (Nematoda: Dracunculoidea)," Journal of Parasitology, vol. 81, no. 5, pp. 792-793, 1995.

[9] J. A. Jackson and R. C. Tinsley, "Hymenochirine anurans (Pinpidae) as transport hosts in camallanid nematode lifecycles," Systematic Parasitology, vol. 39, no. 2, pp. 141-151, 1998.

[10] F. Moravec and B. Škoríková, "Amphibians and larvae of aquatic insects as new paratenic hosts of Anguillicola crassus (Nematoda: Dracunculoidea), a swimbladder parasite of eels," Diseases of Aquatic Organisms, vol. 34, no. 3, pp. 217-222, 1998.

[11] C. E. González and M. I. Hamann, "The first record of amphibians as paratenic hosts of Serpinema larvae (Nematoda; Camallanidae)," Brazilian Journal of Biology, vol. 67, no. 3, pp. 579-580, 2007.
[12] V. G. T. Santos and S. B. Amato, "Rhinella fernandezae (Anura, Bufonidae) a paratenic host of Centrorhynchus sp. (Acanthocephala, Centrorhynchidae) in Brazil," Revista Mexicana de Biodiversidad, vol. 81, no. 1, pp. 53-56, 2010.

[13] V. P. Sharpilo and R. V. Salamatin, "Paratenic parasitism: origins and development of the concept," Kyiv, pp. 235-238, 2005 (Russian), Historical essays, bibliography, with English and Ukranian summary.

[14] A. Okulewicz, "The role of paratenic hosts in the life cycles of helminths," Wiadomości Parazytologiczne, vol. 54, no. 4, pp. 297-301, 2008.

[15] S. O. Aisien, F. B. Ajakaiye, and K. Braimoh, "Helminth parasites of anurans from the savannah-mosaic zone of SouthWestern Nigeria," Acta Parasitologica, vol. 48, no. 1, pp. 47-54, 2003.

[16] S. O. Aisien, F. Ayeni, and I. Ilechie, "Helminth fauna of anurans from the Guinea savanna at New Bussa, Nigeria," African Zoology, vol. 39, no. 1, pp. 133-136, 2004.

[17] S. O. Aisien, A. D. Ugbo, A. N. Ilavbare, and O. Ogunbor, "Endoparasites of amphibians from South-Western Nigeria," Acta Parasitologica, vol. 46, no. 4, pp. 299-305, 2001.

[18] M. S. O. Aisien, S. O. Ogoannah, and A. A. Imasuen, "Helminth parasites of amphibians from a rainforest reserve in South-Western Nigeria," African Zoology, vol. 44, no. 1, pp. $1-7,2009$.

[19] M. S. O. Aisien, S. G. A. Nago, and M.-O. Rödel, "Parasitic infections of amphibians in the Penjari Biosphere Reserve, Benin,” African Zoology, vol. 46, no. 2, pp. 340-349, 2011.

[20] F. N. Odigwe, "Survey of helminth parasites infecting lizards in Benin City, Nigeria. Dissertation submitted in partial fulfillment of the requirement for a B.Sc. Degree (Zoology)," University of Benin, Benin City, Nigeria, 1985.

[21] J. F. A. Sprent, "Ascaridoid nematodes of amphibians and reptiles: Ophidascaris Baylis, 1920," Systematic Parasitology, vol. 11, no. 3, pp. 165-213, 1988.

[22] M. J. Ulmer and H. A. James, "Studies on the Helminth fauna of Iowa. II. Cestodes of Amphibians," Proceedings of the Helminthological Society of Washington, vol. 43, no. 2, pp. 191200, 1976.

[23] V. J. McKenzie, "Human land use and patterns of parasitism in tropical amphibian hosts," Biological Conservation, vol. 137, no. 1, pp. 102-116, 2007.

[24] S. R. Goldberg and C. R. Bursey, "Helminths of two species of frogs, Lithobates taylori and Lithobates vaillanti (Ranidae), from Costa Rica," Caribbean Journal of Science, vol. 43, no. 1, pp. 65-72, 2007.

[25] D. F. Mettrick, "A new cestode, Ophiotaenia ophidex n. sp. from a night-adder, Caurus rhombeatus (Licht) in Southern Rhodesia," Proceedings of the Helminthological Society of Washington, vol. 27, no. 3, pp. 275-278, 1960.

[26] D. F. Mettrick, "Some cestodes of reptiles and amphibians from the Rhodesias," Proceedings of the Zoological Society of London, vol. 141, pp. 239-250, 1963.

[27] C. T. McAllister, P. S. Freed, and D. A. Freed, "Ophiotaenia ophiodex and Ophidascaris sp. in a spotted night adder (Causus maculatus) from Cameroon, West Africa," Journal of Wildlife Diseases, vol. 28, no. 4, pp. 641-642, 1992.

[28] A. De Chambrier, M. Ammann, and T. Scholz, "First species of Ophiotaenia (Cestoda: Proteocephalidea) from Madagascar: O. georgievi sp. N., a parasite of the endemic snake Leioheterodon geayi (Colubridae)," Folia Parasitologica, vol. 57, no. 3, pp. 197-205, 2010.

[29] L. R. Smales, "Acanthocephalans from some frogs and toads (Anura) and chameleons (Squamata) from Tanzania with the 
description of a new species," Journal of Parasitology, vol. 91, no. 6, pp. 1459-1464, 2005.

[30] C. R. Bursey, D. Vrcibradic, F. H. Hatano, and C. F. D. Rocha, "New genus, new species of Acanthocephala (Echinorhynchidae) from the Brazilian frog Hylodes phyllodes (Anura: Leptodactylidae)," Journal of Parasitology, vol. 92, no. 2, pp. 353-356, 2006.

[31] S. E. Bush, D. W. Duszynski, and B. B. Nickol, "Acanthocephala from amphibians in China with the description of a new species of Pseudoacanthocephalus (Echinorhynchida)," Journal of Parasitology, vol. 95, no. 6, pp. 1440-1445, 2009. 

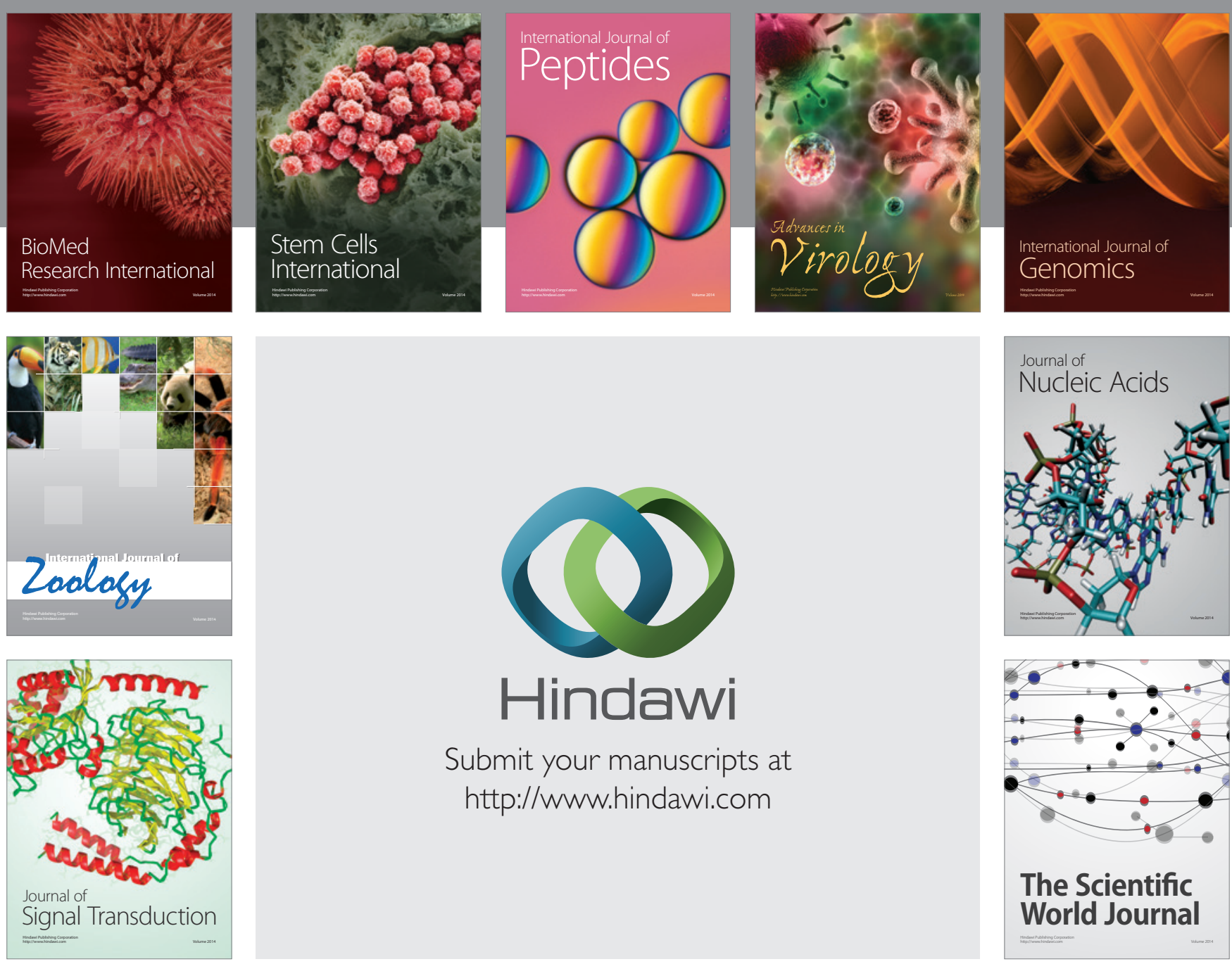

Submit your manuscripts at

http://www.hindawi.com
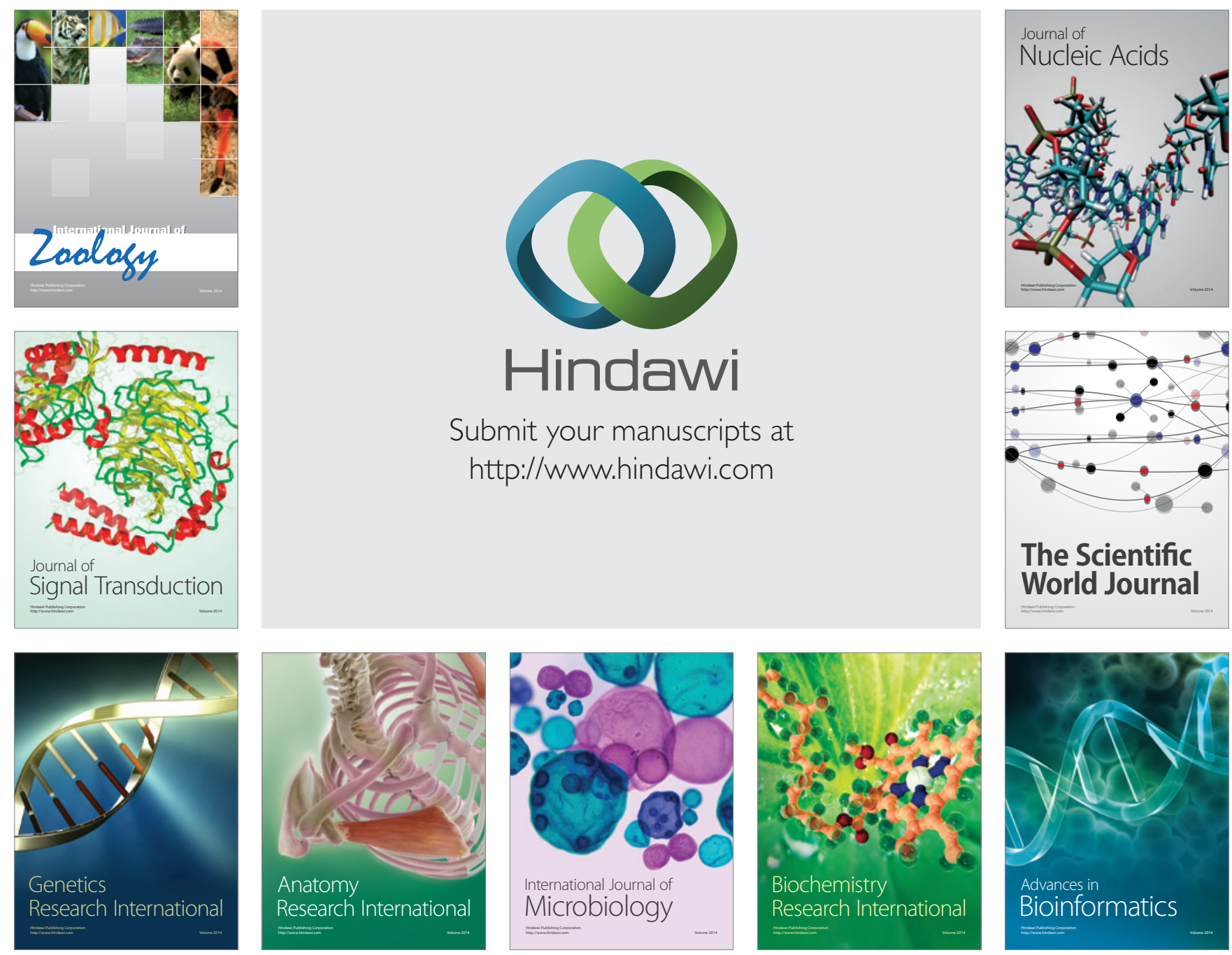

The Scientific World Journal
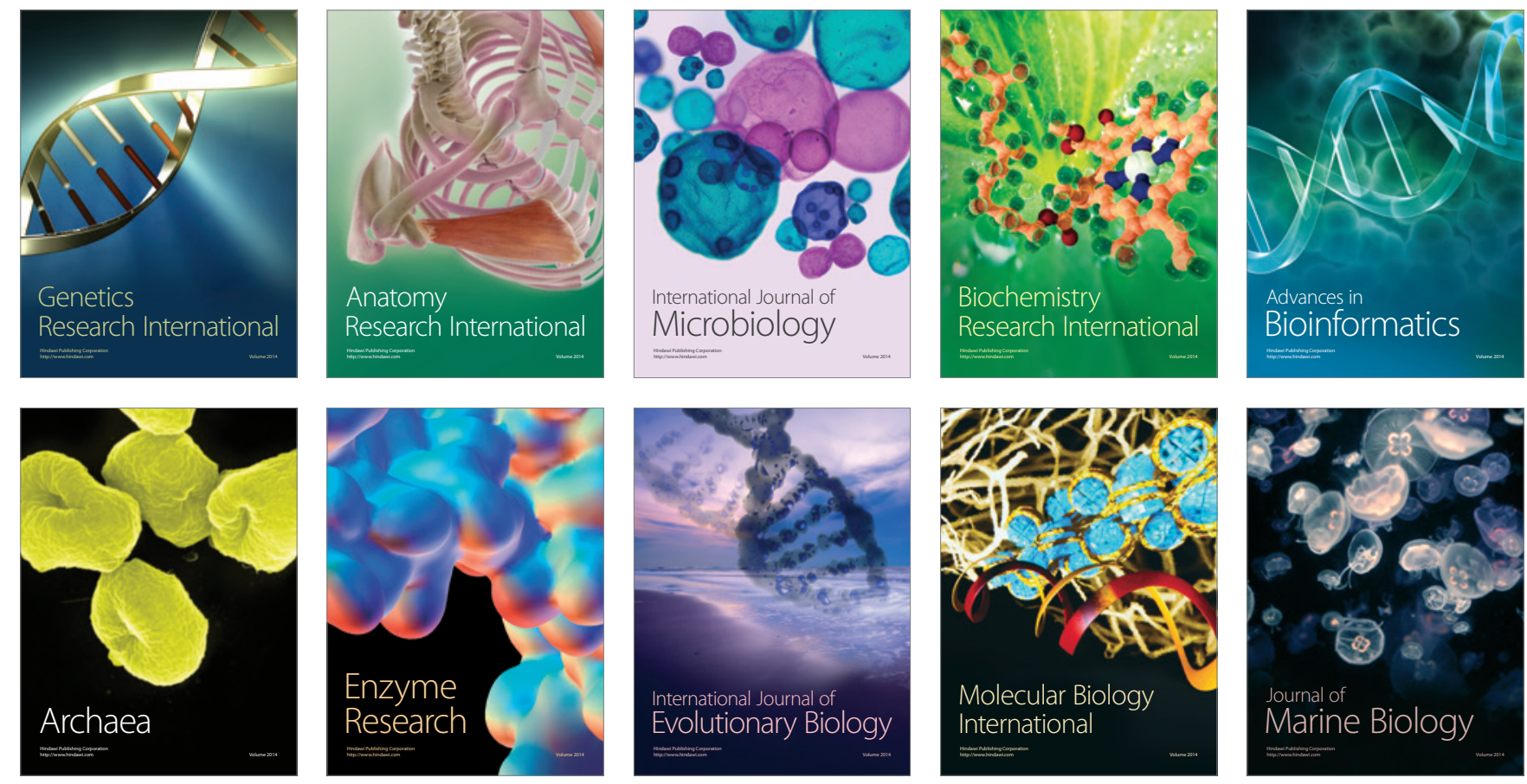